\title{
Cobalt chloride affects the death of SH-SY5Y cells induced by inhibition of ubiquitin proteasome system. Role of heat shock protein 70 and caspase 3
}

\author{
Simona Saksonová, Mária Brodňanová, Katarína Dibdiaková, Ivana Pilchová, Katarína \\ Klačanová, Jozef Hatok and Peter Račay \\ Biomedical Center Martin and Department of Medical Biochemistry, Jessenius Faculty of Medicine in Martin, Comenius \\ University in Bratislava, Martin, Slovakia
}

\begin{abstract}
The aim our study was to investigate protective effect of cobalt chloride $\left(\mathrm{CoCl}_{2}\right)$ in the model of proteasome stress of neuroblastoma SH-SY5Y cells induced by bortezomib, an inhibitor of $26 \mathrm{~S}$ proteasome. We have focused our interests on $\mathrm{Hsp} 70$ and activation of caspase 3. Finally, we have compared the effect of $\mathrm{CoCl}_{2}$ with an effect of the pre-treatment of the cells with 17-AAG, an inhibitor of Hsp90 that is capable to induce expression of Hsp70, or with IOX2, an inhibitor of isoform 2 of prolyl hydroxylase that increases stability of hypoxia-inducible factor $1 \alpha$ (HIF1 $\alpha$ ). Pre-treatment of SH-SY5Y cells for $24 \mathrm{~h}$ with $\mathrm{CoCl}_{2}$, at concentrations of 150 or $250 \mu \mathrm{mol} / \mathrm{l}$, and with $17-\mathrm{AAG}$ at concentration $1 \mu \mathrm{mol} / \mathrm{l}$ but not with IOX2 at concentration $100 \mu \mathrm{mol} / \mathrm{l}$, was associated with significantly increased expression of Hsp70. We have shown that pre-treatment of SH-SY5Y cells with $\mathrm{CoCl}_{2}$ but not with 17-AAG or IOX2 was associated with significant delay of the cell death induced by proteasome stress. $\mathrm{CoCl}_{2}$-mediated effect was consistent with inhibition of bortezomib-induced caspase 3 activation in the cells pre-treated with $\mathrm{CoCl}_{2}$. Despite established neuroprotective properties of $\mathrm{Hsp} 70$ our results do not provide strong evidence that the effect of $\mathrm{CoCl}_{2}$ could be mainly attributed to the ability of $\mathrm{CoCl}_{2}$ to induce expression of $\mathrm{Hsp} 70$ and other mechanisms have to be considered.
\end{abstract}

Key words: Neuroprotection - Ubiquitin proteasome system - Cobalt chloride - Heat shock proteins - Caspase 3

\begin{abstract}
Abbreviations: 17-AAG, 17-N-allylamino-17-demethoxygeldanamycin; AD, Alzheimer's disease; ALS, amyotrophic lateral sclerosis; CHAPS, 3-[(3-cholamidopropyl)dimethylammonio]-1-propanesulfonate hydrate; HD, Huntington's disease; HIF1 $\alpha$, hypoxia-inducible factor $1 \alpha$; Hsp, heat shock protein; MTT, 3-(4,5-dimethylthiazol-2-yl)-2,5-diphenyltetrazolium bromide; OGD, oxygen glucose deprivation; PD, Parkinson's disease; UPS, ubiquitin proteasome system; VHL, von Hippel-Lindau protein.
\end{abstract}

\section{Introduction}

Ubiquitin proteasome system (UPS) represents an important intracellular pathway involved in the control of a wide range of cellular functions like protein stabil-

Correspondence to: Peter Račay, Biomedical Center Martin and Department of Medical Biochemistry, Jessenius Faculty of Medicine in Martin (JFM CU), Comenius University in Bratislava, Mala Hora 4D, SK-03601 Martin, Slovakia

E-mail: racay@jfmed.uniba.sk ity, intracellular protein localization, protein-protein interactions, and transcriptional activity (Glickman and Ciechanover 2002). These effects are mediated by monoor poly-ubiquitinylation of specific proteins involved in the regulation of cell cycle, apoptosis, transcription and signal transduction (Schrader et al. 2009). In addition to regulatory functions, the most prominent function of UPS is elimination of aged and aberrant proteins, including misfolded or aggregated proteins. Proteinopathies that include diverse human pathologies including neurodegenerative disorders such as Alzheimer's disease (AD), 
Parkinson's disease (PD), Huntington's disease (HD) and amyotrophic lateral sclerosis (ALS) are characterised by accumulation of certain structurally abnormal proteins and protein aggregates with consequent disruption of cellular functions (Luheshi and Dobson 2009; Chiti and Dobson 2017; Hartl 2017). Proteasome stress resulting from either UPS overload or dysfunction is considered to be important common mechanism implicated in pathophysiology of mentioned neurodegenerative diseases (Ciechanover and Kwon 2015) as well as ischemic neurodegeneration (Luo et al. 2013; Caldeira et al. 2014). The previous research has documented that aggregates of proteins specific for particular neurodegeneration could itself cause strong inhibition of $26 \mathrm{~S}$ proteasome. The inhibition of proteasome was documented for tau protein associated with AD (Myeku et al. 2016), a-synuclein (Lindersson et al. 2004; Zhang et al. 2008) and parkin (Um et al. 2010) associated with PD, ALS specific proteins (Cheroni et al. 2009) as well as for ubiquitin-conjugated protein aggregates (Bence et al. 2001) produced in early reperfusion phase after global brain ischemia (Racay 2012).

Cobalt in the form of divalent cation is essential to human health since it plays a critical role in the synthesis of vitamin $\mathrm{B}_{12}$. In 1966, the toxic effect of $\mathrm{Co}^{2+}$ attributed to the addition of cobalt sulphate to the beer as a stabilizer (Sullivan et al. 1968) was first described among beer drinkers that developed a cardiomyopathy. In addition to heart, $\mathrm{Co}^{2+}$ exhibited toxic effects on the cells of other organs including cells of nervous tissue (Caltana et al. 2009; Yang et al. 2011; Guo et al. 2013). The mechanism of the detrimental action of $\mathrm{Co}^{2+}$ on the cells is not completely known. Previous studies have demonstrated mitochondrial dysfunction and transmembrane potential collapse caused by opening the mitochondrial transition pore and inhibition of the mitochondrial respiratory chain complexes (Battaglia et al. 2009). In addition, induction of apoptosis (Yang et al. 2004; Jung et al. 2007; Walls et al. 2009; Chang et al. 2016) autophagy (Yang et al. 2015; Fung et al. 2016) and oxidative stress (Chen et al. 2010; Stenger et al. 2011; Guan et al. 2015) has also been documented among the mechanisms of $\mathrm{Co}^{2+}$-induced cell death.

On contrary, pre-treatment of the cells or animals with non-toxic concentrations of $\mathrm{CoCl}_{2} 24 \mathrm{~h}$ prior to lethal insult was documented to be protective in different models of brain ischemia in both neonatal (Bergeron et al. 2000; Jones et al. 2008; Dai et al. 2014) and adult animals (Valsecchi et al. 2011; Wacker et al. 2012) or brain hypoxia injury (Shrivastava et al. 2008). Hypoxia-inducible factor $1 \alpha$ (HIF1 $\alpha$ ) is considered to be essential molecule associated with protective effect of $\mathrm{CoCl}_{2}$ (Sharp et al. 2001; Jones et al. 2013) since $\mathrm{CoCl}_{2}$ is able to stabilize HIF1a, a key determinant of the cellular response to hypoxia. Stabilisation of HIF1a is mediated by inhibitory effect of $\mathrm{Co}^{2+}$ on the isoforms of prolyl hydroxylase, the enzyme responsible for hydroxylation of HIFla protein on specific proline residue. Hydroxylation of HIF1a leads to binding of the von Hippel-Lindau protein (VHL), which recruits an ubiquitin protein-ligase that targets HIF1a for proteasome degradation (Semenza 2011). In addition to stabilisation of HIF1a, $\mathrm{Co}^{2+}$, as the other ions of transition metals, is able to induce expression of heat shock protein 70 (Hsp70) (Koizumi et al. 2013) that also exhibits protective effects in different models of neuronal cell injury (Kelly et al. 2001, Sinn et al. 2007) including brain ischemia (Lee et al. 2001; Matsumori et al. 2005) and other neurodegenerative conditions (Turturici et al. 2011).

In our previous studies, we have shown that proteasome stress is associated with death of SH-SY5Y cells despite induction of Hsp70 expression that was documented already $4 \mathrm{~h}$ after incubation of the cells with bortezomib, inhibitor of 26S proteasome (Klacanova et al. 2016; Pilchova et al. 2017). The aim our study was to investigate impact of the proteasome stress on SH-SY5Y cells pre-treated with $\mathrm{CoCl}_{2}$ $24 \mathrm{~h}$ prior to induction of proteasome stress with bortezomib. We have focused our interests on Hsp70 that was shown to be over-expressed after pre-treatment of the cells with $\mathrm{CoCl}_{2}$ and activation of caspase 3. Finally, we have compared the effect of $\mathrm{CoCl}_{2}$ with an effect of pre-treatment of the cells with 17-N-allylamino-17-demethoxygeldanamycin (17-AAG), an inhibitor of Hsp90 that is capable to induce expression of Hsp70, or with IOX2, an inhibitor of isoform 2 of prolyl hydroxylase that increases stability of HIF1a.

\section{Materials and Methods}

Sodium dodecylsulphate (SDS), bovine serum albumin (BSA), IOX2, 17-AAG, cobalt chloride and (3-(4,5-dimethylthiazol-2-yl)-2,5-diphenyltetrazolium bromide (MTT) (all Sigma-Aldrich), 3-[(3-cholamidopropyl) dimethylammonio]-1-propanesulfonate hydrate (CHAPS) (ApliChem), bortezomib (Santa Cruz Biotechnology), HALT $^{\mathrm{TM}}$ protease inhibitor cocktail (ThermoFisher Scientific), prestained protein standards (BioRad, cat. no. 1610373). Mouse monoclonal antibodies against Hsp27 (SC-13132), Hsp70 (SC-66048), Hsp90 (SC-13119), caspase 3 (SC-271028), HIF1a (SC-71247) and $\beta$-actin (SC-47778) (all Santa Cruz Biotechnology). Goat anti-mouse (A0168) (all Sigma-Aldrich) secondary antibodies conjugated with horse radish peroxidase.

\section{Cell culture and treatment}

SH-SY5Y cells (ATCC) were maintained in DMEM:F12 $(1: 1)$ medium supplemented with $10 \%$ fetal bovine serum, $1 \%$ penicillin-streptomycin (all PAA) at an optimal cell density of $0.5 \times 10^{6}$ cells $/ \mathrm{ml}$ at $37^{\circ} \mathrm{C}$ and $5 \% \mathrm{CO}_{2}$ humidified atmosphere. The media were changed every 3 days. Naïve 
or SH-SY5Y cells pre-treated with $\mathrm{CoCl}_{2}, 17-\mathrm{AAG}$ and IOX2 $24 \mathrm{~h}$ prior to treatment with indicated concentrations of bortezomib $(0,10,20,50 \mathrm{nmol} / \mathrm{l})$ for 24 and 48 hours at $37^{\circ} \mathrm{C}$ and $5 \% \mathrm{CO}_{2}$ humidified atmosphere were at the end of the treatment washed 3 times with ice cold PBS and then re-suspended in a lysis buffer $(30 \mathrm{mmol} / \mathrm{l}$ Tris- $\mathrm{HCl}, 150$ $\mathrm{mmol} / 1 \mathrm{NaCl}, 1 \%$ CHAPS, $1 \times$ protease inhibitor cocktail, $\mathrm{pH}$ 7.6) for total protein extraction. Proteat concentrations were determined by protein Dc assay kit (Bio-Rad) using BSA as standard.

\section{Cell viability}

Cells were seeded in 96-well plates at concentrations of $0.4 \times 10^{6} \mathrm{SH}-\mathrm{SY} 5 Y$ cells per ml. Naïve or SH-SY5Y cells pre-treated with $\mathrm{CoCl}_{2}, 17-\mathrm{AAG}$ and IOX2 $24 \mathrm{~h}$ prior to treatment with bortezomib were incubated for 24 and $48 \mathrm{~h}$ with indicated concentrations of bortezomib $(0,5,10$, $20,50 \mathrm{nmol} / \mathrm{l})$ at $37^{\circ} \mathrm{C}$ in $5 \% \mathrm{CO}_{2}$ humidified atmosphere. At the end of treatment, $0.01 \mathrm{ml}$ of MTT solution $(5 \mathrm{mg} / \mathrm{ml})$ were added to each well and the cells were further incubated for 4 hours at $37^{\circ} \mathrm{C}$ and $5 \% \mathrm{CO}_{2}$ humidified atmosphere. The insoluble formazan, which resulted from oxidation of added MTT by vital cells, was dissolved by addition of $0.1 \mathrm{ml}$ of SDS solution $(0.1 \mathrm{~g} / \mathrm{ml})$ and overnight incubation at $37^{\circ} \mathrm{C}$ and $5 \%$ $\mathrm{CO}_{2}$ humidified atmosphere. The absorbance of formazan was determined spectrophotometrically using microplate reader Bio-Rad 2010. The relative viability of the cells was determined as ratio of optical density of formazan produced by treated cells to optical density of formazan produced by non-treated control cells and expressed as percent of control. For each treatment time, the optical density value of nontreated control cells was considered as $100 \%$ of viable cells.

\section{Western blotting}

Isolated proteins (30 $\mu \mathrm{g}$ of proteins loaded per lane) were separated on $12 \%$ SDS-polyacrylamide gels (PAGE) under reducing conditions. Separated proteins were transferred to nitrocellulose membranes using semidry transfer and membranes were probed with antibodies specific to Hsp90 (1:500), Hsp70 (1:500), Hsp27 (1:500), HIF1a (1:200), caspase 3 (1:200) and $\beta$-actin (1:1000). Further incubation of membranes with particular secondary antibodies (all 1:5000) was followed by visualization of immunopositive bands using the chemiluminiscent substrate SuperSignal West Pico (Thermo Scientific) and Chemidoc XRS system (Bio-Rad). Intensities of specific bands were quantified by Quantity One software (Bio-Rad). The intensities of bands of interest were normalized to corresponding intensities of bands of $\beta$-actin and expressed as intensity of the band of particular protein in treated cells relative to intensity of band in control non-treated cells.

\section{Statistical analysis}

For the comparison of differences in protein expression nontreated and pre-treated cells, one-way ANOVA (GraphPad InStat V2.04a, GraphPad Software) was first carried out to test for differences among all experimental groups followed by the Tukey's test to determine differences between individual groups. The value $p<0.05$ was considered as being significant.

\section{Results}

In order to mimic hypoxic preconditioning, SH-SY5Y cells were pre-treated for $24 \mathrm{~h}$ with $\mathrm{CoCl}_{2}$ at concentrations $150 \mu \mathrm{mol} / \mathrm{l}$ and $250 \mu \mathrm{mol} / \mathrm{l}$. Incubation of SH-SY5Y cells for $24 \mathrm{~h}$ with $\mathrm{CoCl}_{2}$ at concentrations $150 \mu \mathrm{mol} / \mathrm{l}$ and $250 \mu \mathrm{mol} / \mathrm{l}$ was associated with significantly increased expression of Hsp70 to $829 \%(p<0.01)$ and $1321 \%(p<0.001)$ of control, respectively (Fig. 1A). Expression of Hsp27 was also significantly elevated to $337 \%$ of control $(p<0.01)$ in the cells incubated for $24 \mathrm{~h}$ with $\mathrm{CoCl}_{2}$ at concentration $250 \mu \mathrm{mol} / \mathrm{l}$ while expression of Hsp90 was not significantly altered in the cells incubated for $24 \mathrm{~h}$ with $\mathrm{CoCl}_{2}$ at concentrations $150 \mu \mathrm{mol} / \mathrm{l}$ and $250 \mu \mathrm{mol} / \mathrm{l}$. The impact of bortezomib on the relative viability of the SH-SY5Y cells and effect of pretreatment of the SH-SY5Y cells with $\mathrm{CoCl}_{2}$ was assessed by MTT test (Fig. 1B, C). In agreement with our previous results (Klacanova et al. 2016; Pilchova et al. 2017), treatment of SH-SY5Y cells with bortezomib at concentrations $10 \mathrm{nmol} / 1$ and higher for 24 and $48 \mathrm{~h}$ was associated with decreased relative cell viability (Fig. 1B, C). Pre-treatment of the cells with $\mathrm{CoCl}_{2} 24 \mathrm{~h}$ prior to application of bortezomib was associated with significantly higher relative viability of the cells treated $24 \mathrm{~h}$ with bortezomib at concentrations $20 \mathrm{nmol} / \mathrm{l}$ and $50 \mathrm{nmol} / \mathrm{l}$ (Fig. 1B). After $48 \mathrm{~h}$ of treatment, the relative viability of the cells pre-treated with $\mathrm{CoCl}_{2}$ was higher than relative viability of the cells that were not pre-treated however, the difference was not statistically significant (Fig. 1C). Since activation of caspase 3 in SH-SY5Y cells treated with bortezomib for $48 \mathrm{~h}$ was clearly documented in our previous study (Pilchova et al. 2017), we have also investigated impact of pre-treatment of SH-SY5Y cells with $\mathrm{CoCl}_{2}$ on bortezomib-induced activation of caspase 3. As shown on Fig. 1D, activation of caspase 3 in SH-SY5Y cells was documented by decrease of procaspase 3 and appearance of p17 fragment of active caspase 3 . These changes were observed $48 \mathrm{~h}$ after the treatment of the cells with bortezomib at concentrations 10 and 20 and $50 \mathrm{nmol} / \mathrm{l}$. The level of p17 fragment of active caspase 3 was decreased in the SH-SY5Y cells pre-treated with $150 \mu \mathrm{mol} / \mathrm{l} \mathrm{CoCl}_{2}$ and was not observed in the SH-SY5Y cells pre-treated with $250 \mu \mathrm{mol} / 1 \mathrm{CoCl}_{2}$ and then treated with bortezomib at concentrations 10, 20 and 
$50 \mathrm{nmol} / \mathrm{l}$. In addition, bortezomib-induced decrease of the level of non-active procaspase 3 was almost completely reversed in the SH-SY5Y cells pre-treated with either 150 or $250 \mu \mathrm{mol} / \mathrm{l} \mathrm{CoCl}_{2}$ and then treated with 10,20 and $50 \mathrm{nmol} / \mathrm{l}$ of bortezomib.

In order to assess the involvement of Hsp70 in the protection of SH-SY5Y cells against proteasome stress we have also used 17-AAG inhibitor of Hsp90 that is known to induce expression of Hsp70 (Powers and Workman 2007). In fact, incubation of SH-SY5Y cells for $24 \mathrm{~h}$ with $1 \mu \mathrm{mol} / \mathrm{l} 17-\mathrm{AAG}$ was associated with significantly increased expression of Hsp70 to $632 \%(p<0.01)$ of control (Fig. 2A). Expression of Hsp27 was also significantly elevated in the cells incubated with $1 \mu \mathrm{mol} / \mathrm{l} 17$-AAG to $894 \%$ ( $p<0.001)$ of control (Fig.
A

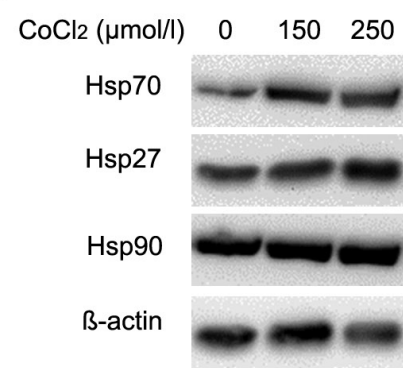

B

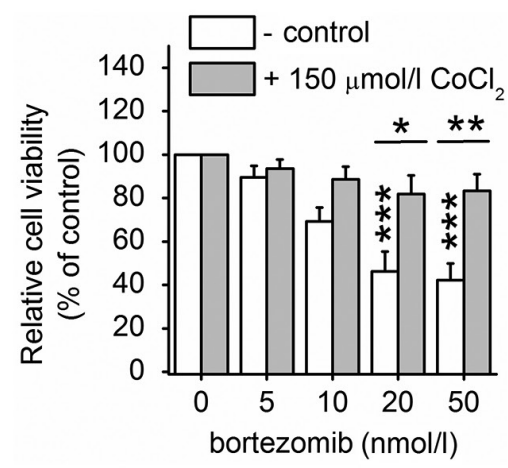

C

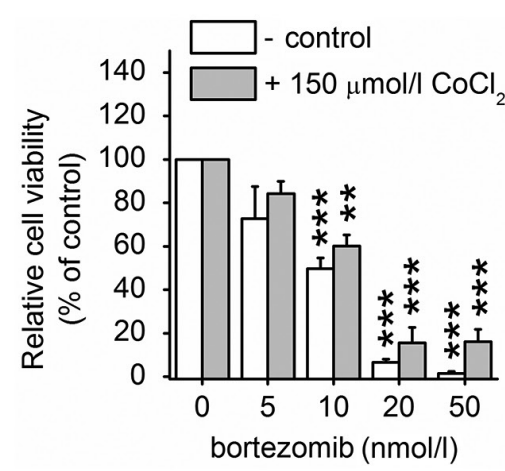

D

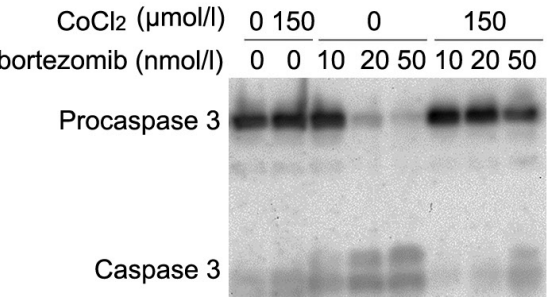

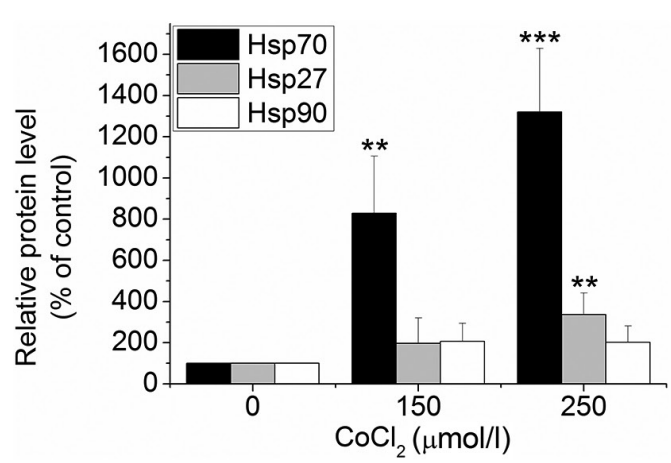
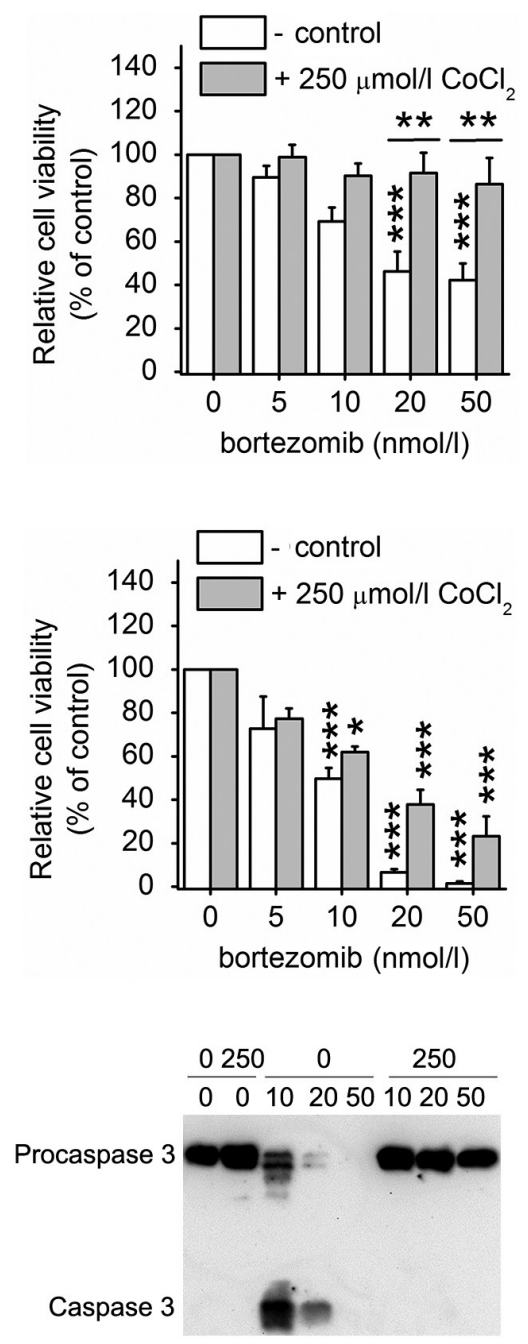

Figure 1. Impact of $\mathrm{CoCl}_{2}$ on expression of heat shock proteins, bortezomib-induced cell death and activation of caspase3. A. Total cell extracts were prepared from SH-SY5Y cells after the pre-treatment with indicated concentrations of $\mathrm{CoCl}_{2}$ for $24 \mathrm{~h}$. The effect of $\mathrm{CoCl}_{2}$ on the levels of Hsp70, Hsp27 and Hsp90 was evaluated by Western blot analysis of total cell extracts as described in Materials and Methods. Data are presented as means $\pm \mathrm{SD}(n=4) .{ }^{*} p<0.05,{ }^{* *} p<$ $0.01,{ }^{* * *} p<0.001$ (one-way ANOVA, followed by Tukey's test to determine differences at the levels of particular proteins between control non-treated cells and cells pre-treated with $\mathrm{CoCl}_{2}$ ). B, C. SH-SY5Y were first pre-treated with indicated concentrations of $\mathrm{CoCl}_{2}$ and then treated with indicated concentrations of bortezomib for 24 (B) and $48 \mathrm{~h}(\mathrm{C})$. After treatment, relative cell viability was determined by MTT test as described in Material and Methods. Data are presented as means \pm SEM (4 independent experiments performed in triplicate). ${ }^{*} p<0.05$, ${ }^{* *} p<0.01$, ${ }^{* *} p<0.001$ (one-way ANOVA followed by Tukey's test to determine differences between relative viability of control cells and cells treated with different concentrations of bortezomib as well as between relative viability of non-pre-treated cells and cells pre-treated with $\mathrm{CoCl}_{2}$ and then treated with particular concentration of bortezomib). D. Total cell extracts were prepared from $\mathrm{SH}-$ SY5Y cells that were either non-pretreated or pre-treated with indicated concentrations of $\mathrm{CoCl}_{2}$ (150 and $250 \mu \mathrm{mol} / \mathrm{l}$ ) and then treated with indicated concentrations of bortezomib $48 \mathrm{~h}$. The activation of caspase 3 was evaluated by Western blot analysis of total cell extracts as described in Materials and Methods. 
2A). Expression of Hsp90 was not significantly altered in the cells incubated for $24 \mathrm{~h}$ with $17-\mathrm{AAG}$ at concentrations $0.5 \mu \mathrm{mol} / \mathrm{l}$ and $1 \mu \mathrm{mol} / \mathrm{l}$ (Fig. 2A). Despite induction of Hsp70 expression, we did not observe significant differences of relative viability of the cells that were pre-treated with 17-AAG after the incubation with bortezomib in comparison to cells that were not pre-treated with 17-AAG but also incubated with bortezomib (Fig. 2B). In accord with the results of MTT test, pre-treatment of SH-SY5Y cells with 17-AAG did not suppress activation of caspase 3 since $\mathrm{p} 17$ fragment of active caspase 3 was observed in the cells treated with bortezomib irrespective of pre-treatment with 17-AAG (Fig. 2C). In addition, decrease of non-active procaspase 3 was observed in both experimental conditions.

Finally, we have pre-treated the cells with IOX2 inhibitor of prolyl hydroxylase 2 that is known to induce expression of HIFla (Chan et al. 2015). Despite some opposing results, HIF1a is considered to be an essential molecule associated with neuroprotection in the model of hypoxic preconditioning induced by $\mathrm{CoCl}_{2}$ (Jones et al. 2013). The level of HIF1a in the cell extracts from control un-treated SH-SY5Y cells was under Western blot detection limit (Fig. 3) but pre-treatment of the cells with IOX 2 at concentration $100 \mu \mathrm{mol} / \mathrm{l}$ was associated with stabilization of HIF1a as documented by detection of proper signal on Western blot (Fig. 3A). Pre-treatment of the cells with IOX2 at concentration $100 \mu \mathrm{mol} / \mathrm{l}$ did not significantly alter expression of Hsp70 and Hsp90 (Fig. 3A) but was associated with significantly increased expression of Hsp27 to $186 \%$ of control $(p<0.05)$. Despite stabilization of HIF1a and increased expression of Hsp27, pre-treatment of the SH-SY5Y cells with IOX2 at concentration $100 \mu \mathrm{mol} / \mathrm{l}$ was not associated with significant differences of relative cell viability as documented by MTT test (Fig. 3B).

\section{Discussion}

We have shown in this study that pre-treatment of $\mathrm{SH}$ SY5Y cells for $24 \mathrm{~h}$ with $\mathrm{CoCl}_{2}$, at concentrations of 150 or $250 \mu \mathrm{mol} / \mathrm{l}$, and with $17-\mathrm{AAG}$ at concentration $1 \mu \mathrm{mol} / \mathrm{l}$ but not with IOX2 at concentration $100 \mu \mathrm{mol} / \mathrm{l}$, was associated with significantly increased expression of Hsp70.
A
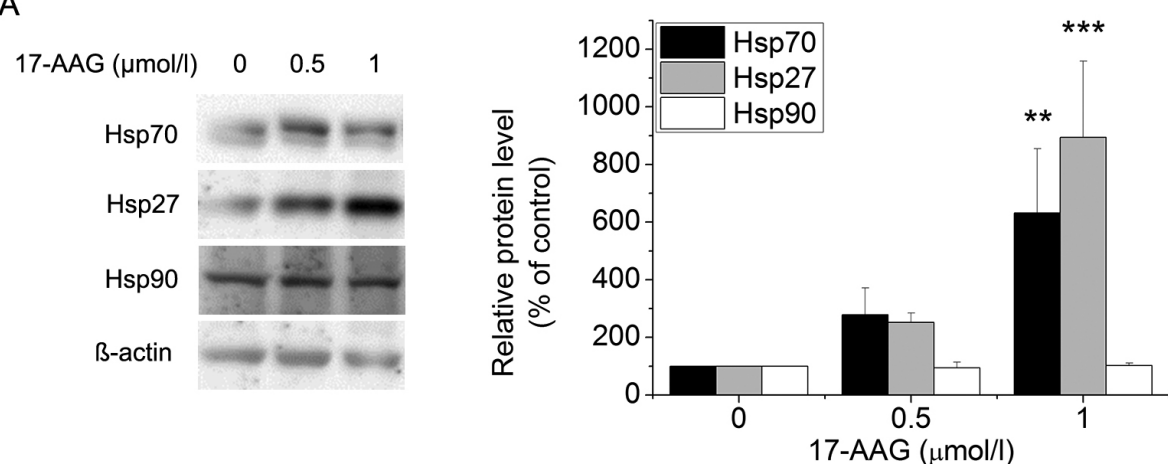

B

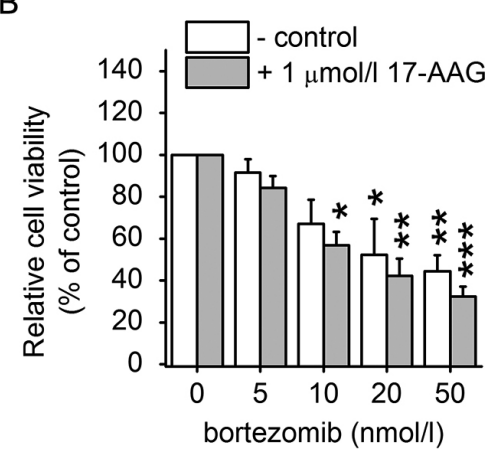

Figure 2. Impact of 17-AAG on expression of heat shock proteins, bortezomib-induced cell death and activation of caspase 3. A. Total cell extracts were prepared from $\mathrm{SH}$ SY5Y cells after the pre-treatment with indicated concentrations of 17-AAG for $24 \mathrm{~h}$. The effect of $17-$ AAG on the levels of Hsp70, Hsp27 and Hsp90 was evaluated by Western blot analysis of total cell extracts as described in Materials and Methods. Data are presented as means $\pm \mathrm{SD}$ $(n=4){ }^{* *} p<0.01,{ }^{* * *} p<0.001$ (oneway ANOVA, followed by Tukey's test to determine differences at the levels of particular proteins between control non-treated cells and cells pre-treated with 17-AAG). B. SH-SY5Y were first pre-treated with 17-AAG and then treated with indicated concentrations of bortezomib for $24 \mathrm{~h}$. After treatment, relative cell viability was determined by MTT test as described in Material and Methods. Data are presented as means \pm SEM (4 independent experiments performed in

triplicate). ${ }^{*} p<0.05,{ }^{* *} p<0.01,{ }^{* * *} p<0.001$ (one-way ANOVA followed by Tukey's test to determine differences between relative viability of control cells and cells treated with different concentrations of bortezomib as well as between relative viability of non-pre-treated cells and cells pre-treated with 17-AAG and then treated with particular concentration of bortezomib). C. Total cell extracts were prepared from SH-SY5Y cells that were either non-pre-treated or pre-treated with 17-AAG and then treated with indicated concentrations of bortezomib $48 \mathrm{~h}$. The activation of caspase 3 was evaluated by Western blot analysis of total cell extracts as described in Materials and Methods. 
A

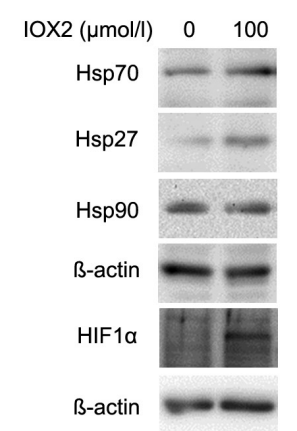

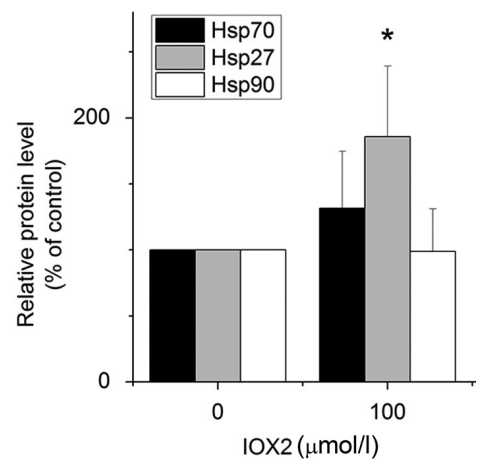

B

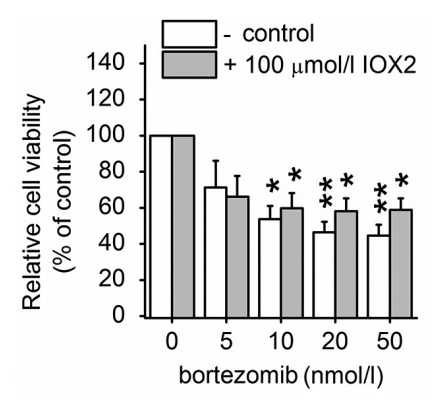

Figure 3. Impact of IOX2 on expression of heat shock proteins, stabilisation of HIFla and bortezomib-induced cell death. A. Total cell extracts were prepared from SH-SY5Y cells after the pre-treatment with IOX2 for $24 \mathrm{~h}$. The effect of IOX2 on the levels of Hsp70, Hsp27, Hsp90 and HIF1a was evaluated by Western blot analysis of total cell extracts as described in Materials and Methods. Data are

presented as means $\pm \operatorname{SD}(n=4) .{ }^{*} p<0.05$ (one-way ANOVA, followed by Tukey's test to determine differences at the levels of particular proteins between control non-treated cells and cells pre-treated with IOX2). B. SH-SY5Y were first pre-treated with IOX2 and then treated with indicated concentrations of bortezomib for $24 \mathrm{~h}$. After treatment, relative cell viability was determined by MTT test as described in Material and Methods. Data are presented as means \pm SEM (four independent experiments performed in triplicate per each cell line). ${ }^{*} p<$ $0.05,{ }^{* *} p<0.01$ (one-way ANOVA followed by Tukey's test to determine differences between relative viability of control cells and cells treated with different concentrations of bortezomib as well as between relative viability of non-pre-treated cells and cells pre-treated with IOX 2 and then treated with particular concentration of bortezomib).

Pre-treatment of SH-SY5Y cells with $\mathrm{CoCl}_{2}$, but not with 17-AAG or IOX2, was associated with significant delay of the cell death induced by proteasome stress. $\mathrm{CoCl}_{2}$-mediated effect was consistent with inhibition of bortezomib-induced caspase 3 activation in the cells pre-treated with $\mathrm{CoCl}_{2}$. Despite established neuroprotective properties of Hsp70 our results do not provide strong evidence that the effect of $\mathrm{CoCl}_{2}$ could be mainly attributed to the ability of $\mathrm{CoCl}_{2}$ to induce expression of Hsp70 since pre-treatment of the cells with 17-AGG.

Cobalt in the form of divalent cation is an essential microelement that at higher concentrations exhibits significant toxicity to the cells of different tissues including cells of nervous system. Detrimental effects of the $\mathrm{Co}^{2+}$ were among other mechanisms attributed to the induction of mitochondrial apoptosis (Lee et al. 2008) including activation of caspase 3 (Zou et al. 2002; Peng et al. 2015; Sun et al. 2015). On contrary, our results have shown that delay of bortezomib-induced cell death might be a result of inhibition of bortezomib-induced caspase 3 activation that was documented in the SH-SY5Y cells pre-treated with subtoxic concentrations of $\mathrm{CoCl}_{2}$. Delay of the cell death after inhibition of caspases was documented in several previous studies. For example, fast apoptotic death of primary hippocampal and cortical neurones induced by ABT-737 that was shown to induce Bax/Bak-dependent mitochondrial apoptosis (Vogler et al. 2009) was not prevented but was significantly delayed by application of the broad spectrum caspase inhibitor zVADfmk (Young et al. 2010). In accord with our results, $\mathrm{CoCl}_{2}$ at concentrations 100 and $200 \mu \mathrm{mol} / \mathrm{l}$ blocked isocudraxanthone-induced apoptosis and activa- tion of caspase 3 (Shin et al. 2014). Concentration of $\mathrm{CoCl}_{2}$ seems to be critical with respect to the impact of $\mathrm{CoCl}_{2}$ on the exposed cells. Pre-treatment of neuronal cells with $\mathrm{CoCl}_{2}$ at concentration $100 \mu \mathrm{mol} / \mathrm{l}$ for $20 \mathrm{~h}$ prior to exposure of the cells to oxygen glucose deprivation (OGD) attenuated OGD-induced neuronal death whereas treatment of the cells with $\mathrm{CoCl}_{2}$ at concentrations 300 or $500 \mu \mathrm{mol} / 1$ induced significant neuronal death, even without exposure to OGD (Jones et al. 2013). Similarly, activation of caspase 3 was documented in mouse cortical HT-22 neurones treated with $\mathrm{CoCl}_{2}$ at concentrations $300 \mu \mathrm{mol} / \mathrm{l}$ and higher (Peng et al. 2015).

It was shown in numerous of the previous studies that heat shock proteins can suppress protein aggregation (Doyle et al. 2013) and toxicity in different models of neurodegenerative diseases (Stetler et al. 2010; Lindberg et al. 2015; Smith et al. 2015). With respect to apoptosis initiation, Hsp70 was shown to act at the level of extrinsic apoptosis (Clemons et al. 2005) as well as caspase-dependent (Beere et al. 2000; Saleh et al. 2000; Stankiewicz et al. 2005) or caspase-independent (Ravagnan et al. 2001) intrinsic (mitochondrial) apoptosis. With respect to neuronal cells, Hsp70 over-expression in rat primary cortical neurons and the SH-SY5Y cells protected the cells in four independent models of apoptosis: etoposide-, staurosporine-, C2-ceramide-, and $\beta$-amyloid-induced apoptosis (Sabirzhanov et al. 2012). It was demonstrated that Hsp70 binds and potentially inactivates apoptotic proteaseactivating factor 1 as well as apoptosis-inducing factor, key molecules involved in the development of caspase-dependent and caspase-independent cell death, respectively (Sabirzhanov et al. 2012). Over-expression of Hsp70 in dopaminergic 
neurones of Drosophila protected them from paraquatinduced cell death via inhibition of caspase 3 activation (Shukla et al. 2014). In addition, Hsp70 is considered to be key molecule conferring protection of CA1 pyramidal cells after preconditioned global brain ischemia (Burda et al. 2003; Tanaka et al. 2004) that is also associated with massive proteasome stress (Racay 2012). In our previous study, we have shown that the sensitivity to bortezomib and kinetics of death of leukemic cells correlated well with higher expression of Hsps in resistant and slowly responding K562 cells (Kliková et al. 2015). Thus, $\mathrm{CoCl}_{2}$-induced massive expression of $\mathrm{Hsp} 70$ might represent plausible molecular mechanism responsible for inhibition of caspase 3 activation and delay of bortezomibinduced death of SH-SY5Y cells.

To prove the involvement of Hsp70 in protection from proteasome stress, we have also pre-treated SH-SY5Y cells with 17-AAG, inhibitor of Hsp90 that was shown to induce of Hsp70 expression (Powers and Workman 2007) and to protect effectively the cells from different form of cellular stress including proteasome stress caused by proteasome inhibition (Bonner et al. 2010). In addition, 17-AAG was tested as neuroprotective molecule in several models of neurodegeneration and pre-clinical studies of neurodegenerative diseases. In our experiments, we did not observe protective effect of 17-AAG. The inability of 17-AAG to protect SH-SY5Y cells from proteasome stress observed in our experiments might be explained by lower extent of Hsp70 induction after pretreatment of the cells with 17-AAG as compared to the levels of $\mathrm{Hsp} 70$ induced by $\mathrm{CoCl}_{2}$. On contrary, despite induction of protective Hsp70 17-AAG exhibits also cytotoxic effects and was tested for treatment of different cancers (Chatterjee and Burns 2017). Although, we did not incubate cells simultaneously with $17-\mathrm{AAG}$ and bortezomib, it is important to note that combination of 17-AAG with bortezomib was associated with synergistic cell death effect on U266 (Duus et al. 2006) and MCF-7 (Mimnaugh et al. 2004) cell lines.

Our results open the possibility that there are some other factors beyond Hsp70 that contributed to the protective effect of $\mathrm{CoCl}_{2}$. For example, Hsp27 was considered to be more protective than Hsp70 in the model of $a$-synucleininduced neuronal cell death (Zourlidou et al. 2004). Hsp27 seems to exert its protective functions via inhibition of extrinsic mitochondria-independent pathway (Tan et al. 2009). Interestingly, the same study showed the protective effect of $\mathrm{Hsp} 27$ against $\mathrm{CoCl}_{2}$-induced apoptosis (Tan et al. 2009) that depends predominately on initiation of mitochondrial apoptosis. In our experiments, expression of Hsp27 was significantly increased after pre-treatment of cells with $250 \mu \mathrm{mol} / \mathrm{l}$ of $\mathrm{CoCl}_{2}$ but not with $150 \mu \mathrm{mol} / \mathrm{l} \mathrm{CoCl}_{2}$. In addition, Hsp27 was shown to be over-expressed in the cells pre-treated with IOX2. Since pre-treatment of the cells with IOX2 was not associated with protective effect and pretreatment with $150 \mu \mathrm{mol} / \mathrm{l}$ of $\mathrm{CoCl}_{2}$ was associated with very similar results as pre-treatment with $250 \mu \mathrm{mol} / \mathrm{l}$ of $\mathrm{CoCl}_{2}$, we consider the involvement of Hsp27 in the effects associated with $\mathrm{CoCl}_{2}$ pre-treatment as unlikely.

Another possibility how to explain effect of $\mathrm{CoCl}_{2}$ consists in the ability of $\mathrm{CoCl}_{2}$ to inhibit prolyl hydroxylases that is associated with stabilisation HIF1a (Jones et al. 2013). To investigate possible involvement of HIF1 $\alpha$ we have pre-treated cells with IOX2 inhibitor of prolyl hydroxylase 2 . The ability of IOX2 to stabilize HIF1a depends on cell type (Chan et al. 2015) but we have clearly documented stabilization of HIF1 $\alpha$ after pre-treatment the SH-SY5Y cells with IOX2 at concentration $100 \mu \mathrm{mol} / \mathrm{l}$. HIF1 $\alpha$ is considered to be critical molecule responsible for protective effect of $\mathrm{CoCl}_{2}$ induced hypoxic preconditioning in different models of ischemic brain injury (Sharp et al. 2001; Jones et al. 2013). On contrary, previous studies indicated that $\mathrm{CoCl}_{2}$ activates HIF1a, acting as a hypoxia-mimetic and inducing reactive oxygen species-mediated toxicity (Chen et al. 2010; Guan et al. 2015). Despite clear stabilisation of HIF1a level after pre-incubation of the cells with IOX2 at concentration 100 $\mu \mathrm{mol} / \mathrm{l}$ we have observed only marginal non-significant effect of this pre-treatment. Thus involvement of HIF1a alone in neuroprotective mechanisms associated with $\mathrm{CoCl}_{2}$ pre-treatment seems to be unlikely but the combined protective effect of both Hsp70 and HIF1 $\alpha$ cannot be completely excluded. Finally, other mechanisms activated by $\mathrm{CoCl}_{2}$, e.g. modulation of expression of Bcl2 family proteins (Shin et al. 2014), could to contribute to protective effects of $\mathrm{CoCl}_{2}$.

In conclusion, we have shown in this study that pretreatment of SH-SY5Y cells with $\mathrm{CoCl}_{2}$ was associated with significant delay of the cells death induced by proteasome stress. In addition, we have shown that $\mathrm{CoCl}_{2}$-mediated protective effect was most probably a result of inhibition of bortezomib-induced caspase 3 activation but the result presented in our study cannot be exclusively attributed to $\mathrm{CoCl}_{2}$-dependent induction of Hsp70.

Acknowledgments. This work was supported by the Slovak Research and Development Agency under the contract No. APVV16-0033 (to PR) and by the project Creating a New Diagnostic Algorithm for Selected Cancer Diseases (ITMS: 26220220022) co-financed from EU sources and European Regional Development Fund.

\section{References}

Battaglia V, Compagnone A, Bandino A, Bragadin M, Rossi CA, Zanetti F, Colombatto S, Grillo MA, Toninello A (2009): Cobalt induces oxidative stress in isolated liver mitochondria responsible for permeability transition and intrinsic apoptosis in hepatocyte primary cultures. Int. J. Biochem. Cell Biol. 41, 586-594

https://doi.org/10.1016/j.biocel.2008.07.012 
Beere HM, Wolf BB, Cain K, Mosser DD, Mahboubi A, Kuwana T, Tailor P, Morimoto RI, Cohen GM, Green DR (2000): Heatshock protein 70 inhibits apoptosis by preventing recruitment of procaspase-9 to the Apaf-1 apoptosome. Nat. Cell Biol. 2, 469-475 https://doi.org/10.1038/35019501

Bence NF, Sampat RM, Kopito RR (2001): Impairment of the ubiquitin-proteasome system by protein aggregation. Science 292, 1552-1555 https://doi.org/10.1126/science.292.5521.1552

Bergeron M, Gidday JM, Yu AY, Semenza GL, Ferriero DM, Sharp FR (2000): Role of hypoxia-inducible factor-1 in hypoxiainduced ischemic tolerance in neonatal rat brain. Ann. Neurol. 48, 285-396 https://doi.org/10.1002/1531-8249(200009)48:3<285::AID-ANA2>3.0.CO;2-8

Bonner HP, Concannon CG, Bonner C, Woods I, Ward MW, Prehn JH (2010): Differential expression patterns of Puma and Hsp70 following proteasomal stress in the hippocampus are key determinants of neuronal vulnerability. J. Neurochem. 114, 606-616 https://doi.org/10.1111/j.1471-4159.2010.06790.x

Burda J, Hrehorovská M, Bonilla LG, Danielisová V, Cízková D, Burda R, Némethová M, Fando JL, Salinas M (2003): Role of protein synthesis in the ischemic tolerance acquisition induced by transient forebrain ischemia in the rat. Neurochem. Res. 28, 1213-1219 https://doi.org/10.1023/A:1024232513106

Caldeira MV, Salazar IL, Curcio M, Canzoniero LM, Duarte CB (2014): Role of the ubiquitin-proteasome system in brain ischemia: friend or foe? Prog. Neurobiol. 112, 50-69 https://doi.org/10.1016/j.pneurobio.2013.10.003

Caltana L, Merelli A, Lazarowski A, Brusco A (2009): Neuronal and glial alterations due to focal cortical hypoxia induced by direct cobalt chloride $(\mathrm{CoCl} 2)$ brain injection. Neurotox. Res. 15, 348-358 https://doi.org/10.1007/s12640-009-9038-9

Chan MC, Atasoylu O, Hodson E, Tumber A, Leung I. K, Chowdhury R, Gómez-Pérez V, Demetriades M, Rydzik AM, HoltMartyn, et al. (2015): Potent and selective triazole-based inhibitors of the hypoxia-inducible factor prolyl-hydroxylases with activity in the murine brain. PLoS One 10, e0132004 https://doi.org/10.1371/journal.pone.0132004

Chang CY, Lui TN, Lin JW, Lin YL, Hsing CH, Wang JJ, Chen RM (2016): Roles of microRNA-1 in hypoxia-induced apoptotic insults to neuronal cells. Arch. Toxicol. 90, 191-202 https://doi.org/10.1007/s00204-014-1364-X

Chatterjee S, Burns TF (2017): Targeting heat shock proteins in cancer: A promising therapeutic approach. Int. J. Mol. Sci. 8, E1978 https://doi.org/10.3390/ijms18091978

Chen SL, Yang CT, Yang ZL, Guo RX, Meng JL, Cui Y, Lan AP, Chen PX, Feng JQ (2010): Hydrogen sulphide protects H9c2 cells against chemical hypoxia-induced injury. Clin. Exp. Pharmacol. Physiol. 37, 316-321 https://doi.org/10.1111/j.1440-1681.2009.05289.x

Cheroni C, Marino M, Tortarolo M, Veglianese P, De Biasi S, Fontana E, Zuccarello L. V, Maynard CJ, Dantuma NP, Bendotti C (2009): Functional alterations of the ubiquitin-proteasome system in motor neurons of a mouse model of familial amyotrophic lateral sclerosis. Hum. Mol. Genet. 18, 82-96 https://doi.org/10.1093/hmg/ddn319

Chiti F, Dobson CM (2017): Protein misfolding, amyloid formation, and human disease: a summary of progress over the last decade. Annu. Rev. Biochem. 86, 27-68 https://doi.org/10.1146/annurev-biochem-061516-045115

Ciechanover A, Kwon YT (2015): Degradation of misfolded proteins in neurodegenerative diseases: therapeutic targets and strategies. Exp. Mol. Med. 47, e147 https://doi.org/10.1038/emm.2014.117

Clemons NJ, Buzzard K, Steel R, Anderson RL (2005): Hsp72 inhibits Fas-mediated apoptosis upstream of the mitochondria in type II cells. J. Biol. Chem. 280, 9005-9012 https://doi.org/10.1074/jbc.M414165200

Dai Y, Li W, Zhong M, Chen J, Liu Y, Cheng Q, Li T (2014): Preconditioning and post-treatment with cobalt chloride in rat model of perinatal hypoxic-ischemic encephalopathy. Brain Dev. 36, 228-240 https://doi.org/10.1016/j.braindev.2013.04.007

Doyle SM, Genest O, Wickner S (2013): Protein rescue from aggregates by powerful molecular chaperone machines. Nat. Rev. Mol. Cell Biol. 14, 617-629 https://doi.org/10.1038/nrm3660

Duus J, Bahar HI, Venkataraman G, Ozpuyan F, Izban KF, Al-Masri H, Maududi T, Toor A, Alkan S (2006): Analysis of expression of heat shock protein-90 (HSP90) and the effects of HSP90 inhibitor (17-AAG) in multiple myeloma. Leuk. Lymphoma 47, 1369-1378 https://doi.org/10.1080/10428190500472123

Fung FK, Law BY, Lo AC (2016): Lutein attenuates both apoptosis and autophagy upon cobalt (ii) chloride-induced hypoxia in rat Müller cells. PLoS One 11, e0167828 https://doi.org/10.1371/journal.pone.0167828

Glickman MH, Ciechanover A (2002): The ubiquitin-proteasome proteolytic pathway: destruction for the sake of construction. Physiol. Rev. 82, 373-428

https://doi.org/10.1152/physrev.00027.2001

Guan D, Su Y, Li Y, Wu C, Meng Y, Peng X, Cui Y (2015): Tetramethylpyrazine inhibits $\mathrm{CoCl} 2$-induced neurotoxicity through enhancement of Nrf2/GCLc/GSH and suppression of HIF1a/ NOX2/ROS pathways. J. Neurochem. 134, 551-565 https://doi.org/10.1111/jnc.13161

Guo L, Lan J, Lin Y, Guo P, Nie Q, Mao Q, Ren L, Qiu Y (2013): Hypoxia/ischemia up-regulates Id 2 expression in neuronal cells in vivo and in vitro. Neurosci. Lett. 554, 88-93 https://doi.org/10.1016/j.neulet.2013.08.044

Hartl FU (2017): Protein misfolding diseases. Annu. Rev. Biochem. 20, 86, 21-26 https://doi.org/10.1146/annurev-biochem-061516-044518

Jones NM, Kardashyan L, Callaway JK, Lee EM, Beart PM (2008): Long-term functional and protective actions of preconditioning with hypoxia, cobalt chloride, and desferrioxamine against hypoxic-ischemic injury in neonatal rats. Pediatr. Res. 63, 620-624

https://doi.org/10.1203/PDR.0b013e31816d9117

Jones SM, Novak AE, Elliott JP (2013): The role of HIF in cobaltinduced ischemic tolerance. Neuroscience 252, 420-430 
https://doi.org/10.1016/j.neuroscience.2013.07.060

Jung JY, Mo HC, Yang KH, Jeong YJ, Yoo HG, Choi NK, Oh WM, Oh HK, Kim SH, Lee JH, Kim HJ, Kim WJ (2007): Inhibition by epigallocatechin gallate of $\mathrm{CoCl} 2$-induced apoptosis in rat PC12 cells. Life Sci. 80, 1355-1363 https://doi.org/10.1016/j.lfs.2006.11.033

Kelly S, Bieneman A, Horsburgh K, Hughes D, Sofroniew MV, McCulloch J, Uney JB (2001): Targeting expression of hsp70i to discrete neuronal populations using the Lmo-1 promoter: assessment of the neuroprotective effects of hsp70i in vivo and in vitro. J. Cereb. Blood Flow Metab. 21, 972-981 https://doi.org/10.1097/00004647-200108000-00010

Klacanova K, Pilchova I, Klikova K, Racay P (2016): Short chemical ischemia triggers phosphorylation of eif $2 \alpha$ and death of sh-sy5y cells but not proteasome stress and heat shock protein response in both SH-SY5Y and T98G cells. J. Mol. Neurosci. 58, 497-506 https://doi.org/10.1007/s12031-015-0685-4

Kliková K, Štefaniková A, Pilchová I, Hatok J, Chudý P, Chudej J, Dobrota D, Račay P (2015): Differential impact of bortezomib on HL-60 and K562 cells. Gen. Physiol. Biophys. 34, 33-42 doi: 10.4149/gpb_2014026 https://doi.org/10.4149/gpb_2014026

Koizumi S, Suzuki K, Yamaguchi S (2013): Heavy metal response of the heat shock protein 70 gene is mediated by duplicated heat shock elements and heat shock factor 1. Gene 522, 184-191 https://doi.org/10.1016/j.gene.2013.03.090

Lee JE, Yenari MA, Sun GH, Xu L, Emond MR, Cheng D, Steinberg GK, Giffard RG (2001): Differential neuroprotection from human heat shock protein 70 overexpression in in vitro and in vivo models of ischemia and ischemia-like conditions. Exp. Neurol. 170, 129-139

https://doi.org/10.1006/exnr.2000.7614

Lee M, Lapham A, Brimmell M, Wilkinson H, Packham G (2008): Inhibition of proteasomal degradation of Mcl-1 by cobalt chloride suppresses cobalt chloride-induced apoptosis in HCT116 colorectal cancer cells. Apoptosis 13, 972-982 https://doi.org/10.1007/s10495-008-0229-2

Lindberg I, Shorter J, Wiseman RL, Chiti F, Dickey CA, McLean PJ (2015): Chaperones in Neurodegeneration. J. Neurosci. 35, 13853-13859 https://doi.org/10.1523/JNEUROSCI.2600-15.2015

Lindersson E, Beedholm R, Højrup P, Moos T, Gai W, Hendil KB, Jensen PH (2004): Proteasomal inhibition by alpha-synuclein filaments and oligomers. J. Biol. Chem. 279, 12924-12934 https://doi.org/10.1074/jbc.M306390200

Luheshi LM, Dobson CM (2009): Bridging the gap: from protein misfolding to protein misfolding diseases. FEBS Lett. 583, 2581-2586 https://doi.org/10.1016/j.febslet.2009.06.030

Luo T, Park Y, Sun X, Liu C, Hu B (2013): Protein misfolding, aggregation, and autophagy after brain ischemia. Transl. Stroke Res. 4, 581-588 https://doi.org/10.1007/s12975-013-0299-5

Matsumori Y, Hong SM, Aoyama K, Fan Y, Kayama T, Sheldon RA, Vexler ZS, Ferriero DM, Weinstein PR, Liu J (2005): Hsp70 overexpression sequesters AIF and reduces neonatal hypoxic/ ischemic brain injury. J. Cereb. Blood Flow Metab. 25, 899-910 https://doi.org/10.1038/sj.jcbfm.9600080
Mimnaugh EG, Xu W, Vos M, Yuan X, Isaacs JS, Bisht KS, Gius D, Neckers L (2004): Simultaneous inhibition of hsp 90 and the proteasome promotes protein ubiquitination, causes endoplasmic reticulum-derived cytosolic vacuolization, and enhances antitumor activity. Mol. Cancer Ther. 3, 551-566

Myeku N, Clelland CL, Emrani S, Kukushkin NV, Yu WH, Goldberg AL, Duff KE (2016): Tau-driven 26S proteasome impairment and cognitive dysfunction can be prevented early in disease by activating cAMP-PKA signaling. Nat. Med. 22, 46-53 https://doi.org/10.1038/nm.4011

Peng C, Rao W, Zhang L, Wang K, Hui H, Wang L, Su N, Luo P, Hao YL, Tu Y, Zhang S, Fei Z (2015): Mitofusin 2 ameliorates hypoxia-induced apoptosis via mitochondrial function and signaling pathways. Int. J. Biochem. Cell Biol. 69, 29-40 https://doi.org/10.1016/j.biocel.2015.09.011

Pilchova I, Klacanova K, Dibdiakova K, Saksonova S, Stefanikova A, Vidomanova E, Lichardusova L, Hatok J, Racay P (2017): Proteasome stress triggers death of SH-SY5Y and T98G cells via different cellular mechanisms. Neurochem. Res. 2, 3170-3185 https://doi.org/10.1007/s11064-017-2355-0

Powers MV, Workman P (2007): Inhibitors of the heat shock response: biology and pharmacology. FEBS Lett. 581, 3758-3769 https://doi.org/10.1016/j.febslet.2007.05.040

Racay P (2012): Ischaemia-induced protein ubiquitinylation is differentially accompanied with heat-shock protein 70 expression after naïve and preconditioned ischaemia. Cell. Mol. Neurobiol. 32, $107-119$

https://doi.org/10.1007/s10571-011-9740-z

Ravagnan L, Gurbuxani S, Susin SA, Maisse C, Daugas E, Zamzami N, Mak T, Jäättelä M, Penninger JM, Garrido C, Kroemer G (2001): Heat-shock protein 70 antagonizes apoptosis-inducing factor. Nat. Cell Biol. 3, 839-843 https://doi.org/10.1038/ncb0901-839

Sabirzhanov B, Stoica BA, Hanscom M, Piao CS, Faden AI (2012): Over-expression of HSP70 attenuates caspase-dependent and caspase-independent pathways and inhibits neuronal apoptosis. J. Neurochem. 123, 542-554 https://doi.org/10.1111/j.1471-4159.2012.07927.x

Saleh A, Srinivasula SM, Balkir L, Robbins PD, Alnemri ES (2000): Negative regulation of the Apaf-1 apoptosome by Hsp70. Nat. Cell Biol. 2, 476-483 https://doi.org/10.1038/35019510

Schrader EK, Harstad KG, Matouschek A (2009): Targeting proteins for degradation. Nat. Chem. Biol. 5, 815-822 https://doi.org/10.1038/nchembio.250

Semenza GL (2011): Hypoxia-inducible factor 1: regulator of mitochondrial metabolism and mediator of ischemic preconditioning. Biochim. Biophys. Acta 1813, 1263-1268 https://doi.org/10.1016/j.bbamcr.2010.08.006

Sharp FR, Bergeron M, Bernaudin M (2001): Hypoxia-inducible factor in brain. Adv. Exp. Med. Biol. 502, 273-291 https://doi.org/10.1007/978-1-4757-3401-0_18

Shin MR, Lee HJ, Kang SK, Auh QS, Lee YM, Kim YC, Kim EC (2014): Isocudraxanthone $\mathrm{K}$ induces growth inhibition and apoptosis in oral cancer cells via hypoxia inducible factor- $1 \alpha$. Biomed. Res. Int. 2014, 934691 https://doi.org/10.1155/2014/934691 
Shrivastava K, Shukla D, Bansal A, Sairam M, Banerjee PK, Ilavazhagan G (2008): Neuroprotective effect of cobalt chloride on hypobaric hypoxia-induced oxidative stress. Neurochem. Int. 52, 368-375 https://doi.org/10.1016/j.neuint.2007.07.005

Shukla AK, Pragya P, Chaouhan HS, Tiwari AK, Patel DK, Abdin MZ, Chowdhuri DK (2014): Heat shock protein-70 (Hsp-70) suppresses paraquat-induced neurodegeneration by inhibiting JNK and caspase- 3 activation in Drosophila model of Parkinson's disease. PLoS One 9, e98886 https://doi.org/10.1371/journal.pone.0098886

Sinn DI, Chu K, Lee ST, Song EC, Jung KH, Kim EH, Park DK, Kang KM, Kim M, Roh JK (2007): Pharmacological induction of heat shock protein exerts neuroprotective effects in experimental intracerebral hemorrhage. Brain Res. 1135, 167-176 https://doi.org/10.1016/j.brainres.2006.11.098

Smith HL, Li W, Cheetham ME (2015): Molecular chaperones and neuronal proteostasis. Semin. Cell. Dev. Biol. 40, 142-152 https://doi.org/10.1016/j.semcdb.2015.03.003

Stankiewicz AR, Lachapelle G, Foo CP, Radicioni SM, Mosser DD (2005): Hsp70 inhibits heat-induced apoptosis upstream of mitochondria by preventing Bax translocation. J. Biol. Chem. 280, 38729-38739 https://doi.org/10.1074/jbc.M509497200

Stenger C, Naves T, Verdier M, Ratinaud MH (2011): The cell death response to the ROS inducer, cobalt chloride, in neuroblastoma cell lines according to p53 status. Int. J. Oncol. 39, 601-609 https://doi.org/10.3892/ijo.2011.1083

Stetler RA, Gan Y, Zhang W, Liou AK, Gao Y, Cao G, Chen J (2010): Heat shock proteins: cellular and molecular mechanisms in the central nervous system. Prog. Neurobiol. 92, 184-211 https://doi.org/10.1016/j.pneurobio.2010.05.002

Sullivan J, Parker M, Carson SB (1968): Tissue cobalt content in ,beer drinkers' myocardiopathy. J. Lab. Clin. Med. 71, 893-911

Sun L, Liu N, Liu SS, Xia WY, Liu MY, Li LF, Gao JX (2015): Beclin1 -independent autophagy mediates programmed cancer cell death through interplays with endoplasmic reticulum and/ or mitochondria in colbat chloride-induced hypoxia. Am. J. Cancer Res. 5, 2626-2642

Tan CY, Ban H, Kim YH, Lee SK (2009): The heat shock protein 27 (Hsp27) operates predominantly by blocking the mitochondrial-independent/extrinsic pathway of cellular apoptosis. Mol. Cells 27, 533-538 https://doi.org/10.1007/s10059-009-0079-y

Tanaka H, Yokota H, Jover T, Cappuccio I, Calderone A, Simionescu M, Bennett MV, Zukin RS (2004): Ischemic preconditioning: neuronal survival in the face of caspase- 3 activation. J. Neurosci. 24, 2750-2759 https://doi.org/10.1523/JNEUROSCI.5475-03.2004

Turturici G, Sconzo G, Geraci F (2011): Hsp70 and its molecular role in nervous system diseases. Biochem. Res. Int. 2011, 618127 https://doi.org/10.1155/2011/618127

Um JW, Im E, Lee HJ, Min B, Yoo L, Yoo J, Lübbert H, StichelGunkel C, Cho HS, Yoon JB, Chung KC (2010): Parkin directly modulates $26 \mathrm{~S}$ proteasome activity. J. Neurosci. 30, 11805-11814 https://doi.org/10.1523/JNEUROSCI.2862-09.2010
Valsecchi V, Pignataro G, Del Prete A, Sirabella R, Matrone C, Boscia F, Scorziello A, Sisalli MJ, Esposito E, Zambrano N, Di Renzo G, Annunziato L (2011): NCX1 is a novel target gene for hypoxia-inducible factor- 1 in ischemic brain preconditioning. Stroke 42, 754-763 https://doi.org/10.1161/STROKEAHA.110.597583

Vogler M, Weber K, Dinsdale D, Schmitz I, Schulze-Osthoff K, Dyer MJ, Cohen GM (2009): Different forms of cell death induced by putative BCL2 inhibitors. Cell Death Differ. 16, 1030-1039 https://doi.org/10.1038/cdd.2009.48

Wacker BK, Perfater JL, Gidday JM (2012): Hypoxic preconditioning induces stroke tolerance in mice via a cascading HIF, sphingosine kinase, and CCL2 signaling pathway. J. Neurochem. 123, 954-962 https://doi.org/10.1111/jnc.12047

Walls KC, Ghosh AP, Ballestas ME, Klocke BJ, Roth KA (2009): bcl-2/Adenovirus E1B 19-kd interacting protein 3 (BNIP3) regulates hypoxia-induced neural precursor cell death. J. Neuropathol. Exp. Neurol. 68, 1326-1338

https://doi.org/10.1097/NEN.0b013e3181c3b9be

Yang SJ, Pyen J, Lee I, Lee H, Kim Y, Kim T (2004): Cobalt chlorideinduced apoptosis and extracellular signal-regulated protein kinase 1/2 activation in rat C6 glioma cells. J. Biochem. Mol. Biol. 37, 480-486

Yang T, Li D, Liu F, Qi L, Yan G, Wang M (2015): Regulation on Beclin-1 expression by mTOR in CoCl2-induced HT22 cell ischemia-reperfusion injury. Brain Res. 1614, 60-66 https://doi.org/10.1016/j.brainres.2015.04.016

Yang YF, Chen Z, Hu SL, Hu J, Li B, Li JT, Wei LJ, Qian ZM, Lin JK, Feng H, Zhu G (2011): Interleukin-1 receptor associated kinases-1/4 inhibition protects against acute hypoxia/ischemiainduced neuronal injury in vivo and in vitro. Neuroscience $196,25-34$ https://doi.org/10.1016/j.neuroscience.2011.08.059

Young KW, Pi-ón LG., Dhiraj D, Twiddy D, Macfarlane M, Hickman J, Nicotera P (2010): Mitochondrial fragmentation and neuronal cell death in response to the $\mathrm{Bcl}-2 / \mathrm{Bcl}-\mathrm{x}(\mathrm{L}) / \mathrm{Bcl}-\mathrm{w}$ antagonist ABT-737. Neuropharmacology 58, 1258-1267 https://doi.org/10.1016/j.neuropharm.2010.03.008

Zhang NY, Tang Z, Liu CW (2008): alpha-Synuclein protofibrils inhibit $26 \mathrm{~S}$ proteasome-mediated protein degradation: understanding the cytotoxicity of protein protofibrils in neurodegenerative disease pathogenesis. J. Biol. Chem. 283, 20288-20298 https://doi.org/10.1074/jbc.M710560200

Zou W, Zeng J, Zhuo M, Xu W, Sun L, Wang J, Liu X. (2002): Involvement of caspase- 3 and p38 mitogen-activated protein kinase in cobalt chloride-induced apoptosis in PC12 cells. J. Neurosci. Res. 67, 837-843 https://doi.org/10.1002/jnr.10168

Zourlidou A, Payne Smith MD, Latchman DS (2004): HSP27 but not HSP70 has a potent protective effect against alphasynuclein-induced cell death in mammalian neuronal cells. J. Neurochem. 88, 1439-1448 https://doi.org/10.1046/j.1471-4159.2003.02273.x

Received: March 26, 2018

Final version accepted: June 18, 2018 